\title{
PENGARUH HIDROLISIS FUKOIDAN TERHADAP AKTIVITASNYA SEBAGAI ANTIOKSIDAN
}

\section{Effect of Fucoidan Hydrolysis on Its Activity as an Antioxidant}

\author{
Ellya Sinurat ${ }^{1 \star}$ dan Nurun Nisa Maulida ${ }^{2}$ \\ ${ }^{1}$ Balai Besar Riset Pengolahan Produk dan Bioteknologi Kelautan dan Perikanan, Badan Riset dan Sumber Daya Manusia \\ Kelautan dan Perikanan, JI. KS.Tubun Petamburan VI, Slipi, Jakarta, Indonesia \\ 2 Departemen Kimia, Fakultas Matematika dan IImu Pengetahuan Alam, Universitas Indonesia, Depok, Indonesia \\ *Korespondensi Penulis: ellya_sinurat@yahoo.com
}

Diterima: 2 Mei 2018; Direvisi: 23 Agustus 2018; Disetujui: 30 November 2018

\begin{abstract}
ABSTRAK
Fukoidan merupakan jenis heteropolisakarida yang terdiri dari fukosa dan gugus ester sulfat sebagai penyusun utamanya. Salah satu sumber fukoidan adalah rumput laut cokelat. Telah dilakukan isolasi fukoidan dari rumput laut cokelat Sargassum crassifolium yang diperoleh dari Lampung Selatan. Penelitian ini bertujuan untuk mengetahui pengaruh hidrolisis fukoidan terhadap aktivitasnya sebagai antioksidan. Ekstraksi fukoidan menggunakan $\mathrm{HCl} \mathrm{0,1} \mathrm{N}$. Selanjutnya proses optimasi hidrolisis fukoidan menggunakan TFA 1,5 M dengan variasi waktu 30, 60, 90 dan 120 menit pada suhu $121^{\circ} \mathrm{C}$. Untuk mengetahui karakteristik gugus fungsi crude fukoidan dan fukoidan hasil hidrolisis dilakukan dengan menggunakan Fourier Transform Infrared Spectrometer (FT-IR). Selanjutnya dilakukan karakterisasi fukoidan yang meliputi uji total polisakarida dan uji kadar sulfat. Uji antioksidan fukoidan dilakukan dengan metode 2,2-diphenyl-1-picryl-hydrazyl-hydrate (DPPH). Diperoleh rendemen fukoidan sebesar $23,82 \%$ dari berat rumput laut kering, total polisakarida dari crude fukoidan sebesar 50,69\% dan kadar sulfatnya sebesar 19,44\%. Dari hasil penelitian diperoleh waktu optimum hidrolisis fukoidan yaitu selama 90 menit dengan total polisakarida dan kandungan sulfatnya masing-masing 43,56\% dan $13,09 \%$. Diperoleh nilai $I_{50}$ crude fucoidan lebih tinggi dibandingkan dengan semua hasil hidrolisis fukoidan.
\end{abstract}

KATA KUNCl: rumput laut cokelat, fukoidan, hidrolisis, konsentrasi penghambatan, aktivitas antioksidan

\begin{abstract}
Fucoidan is a heteropolysaccharide type consisting of a fucose and a sulfated ester group as its main constituent. One source of fucoidan is brown seaweed. Fucoidan extraction from brown seaweed Sargassum crassifolium obtained from South Lampung was carried out. This study aims to determine the effect of fucoidan hydrolysis on its activity as an antioxidant. Fucoidan was extracted using $0.1 \mathrm{~N}$ $\mathrm{HCl}$ and hydrolized using $1.5 \mathrm{M}$ TFA for 30, 60, 90, and 120 minutes at $121^{\circ} \mathrm{C}$. The characteristics of the functional groups from crude fucoidan and the hydrolyzed fucoidan were carried out using the Fourier Transform Infrared Spectrometer (FT-IR). Furthermore, fucoidan was characterized by analyzing of total polysaccharide and sulfate contents. The fucoidan antioxidant test was carried out by 2,2-diphenyl-1-picryl-hydrazyl-hydrate (DPPH) method. The result showed that the yield of fucoidan was $23.82 \%$ per dry weight with the total polysaccharide and sulfate content from crude fucoidan was 50.69 and $19.44 \%$, respectively. The optimum time for fucoidan hydrolysis was 90 minutes with the total polysaccharide and sulfate content of $43.56 \%$ and $13.09 \%$, respectively. The $I C_{50}$ value of crude fucoidan was higher than that of hydrolyzed fucoidans.
\end{abstract}

\section{KEYWORDS: brown seaweed, fucoidan, hydrolysis, inhibition concentration, antioxidant activity}

\section{PENDAHULUAN}

Di Indonesia terdapat banyak jenis rumput laut yang di antaranya bernilai ekonomis cukup tinggi seperti alga cokelat Sargassum yang memiliki kelimpahan tinggi dan tersebar luas di perairan Indonesia. Umumnya, rumput laut tumbuh di daerah perairan yang dangkal dengan kondisi dasar perairan berpasir, sedikit berlumpur, atau campuran keduanya. Rumput laut memiliki sifat benthic (melekat) dan disebut benthic algae. Pelekatan rumput laut ini dilakukan dengan cara melekatkan talus pada substrat pasir, lumpur berpasir, karang, fragmen karang mati, kulit kerang, batu atau kayu. Rumput laut jenis Sargassum mampu tumbuh pada substrat batu karang di daerah berombak (Anggadiredja, 2006). Penyebaran 
spesies ini banyak terdapat di perairan Indonesia seperti Sumatera, Jawa, Kepulauan Seribu, Sulawesi, Lombok, dan Aru. Tumbuhan ini memiliki nilai ekonomi tinggi tidak hanya pada industri pangan tetapi juga industri kosmetik, tekstil, dan farmasi (Indriani \& Sumiarsih, 1992).

Rumput laut cokelat mengandung metabolit sekunder yaitu alkaloid, glikosida, tanin dan steroid yang banyak digunakan dalam pengobatan dan industri farmasi (Jeeva, Marimuthu, Domettila, Anantham, \& Mahesh, 2012). Senyawa fenolik pada alga cokelat memiliki komponen yang tidak terpisahkan dari dinding sel dan memiliki berbagai fungsi perlindungan dari radiasi sinar UV, berperan dalam reproduksi alga dan mekanisme perlindungan terhadap faktor biotik serta memiliki sifat terapeutik (Machu et al. 2015). Beberapa senyawa bioaktif yang ada di dalam rumput laut cokelat di antaranya fukoidan, fukosantin, polifenol, alginat, dan laminaran. Fukoidan merupakan sejenis polisakarida sulfat yang ditemukan pada struktur dinding sel rumput cokelat yang mengandung fukosa sebagai komponen utamanya (Li, Lou, Yuan, \& Yu, 2017). Secara alami fukoidan berfungsi untuk melindungi tanaman rumput laut cokelat dari patogen-patogen yang terlarut dalam air laut. Tidak semua struktur dan ukuran molekul fukoidan sama, hal ini tergantung dari jalur biosintesis dari fukoidan itu sendiri. Fukoidan merupakan senyawa alami yang telah banyak diteliti dan terbukti memiliki bioaktivitas yang bermanfaat untuk kesehatan manusia (Sinurat, Saepudin, \& Peranginangin, 2015).

Proses ekstraksi fukoidan sangat menentukan sifat dan kemampuan bioaktivitasnya. Proses isolasi fukoidan biasanya menggunakan pelarut air atau $\mathrm{HCl}$ $0,1 \mathrm{~N}(1: 20)$ pada waterbath dengan suhu $80-85^{\circ} \mathrm{C}$ selama 6 jam. Pelarut yang digunakan dalam proses isolasi mempengaruhi hasil rendemen dari ekstrak fukoidan yang dihasilkan, seperti perbedaan total polisakarida, kandungan sulfat, jumlah pengotor serta warna ekstrak yang dihasilkan. Ekstraksi menggunakan air menghasilkan rendemen yang relatif rendah, sedangkan ekstraksi menggunakan asam menghasilkan redemen yang lebih tinggi. Meskipun demikian, pada ekstraksi menggunakan asam semua material sel alga juga akan terbawa ke dalam ekstrak yang dihasilkan (Sinurat et al., 2015). Kelemahan ekstraksi menggunakan air yaitu rendemen yang diperoleh sangat rendah tetapi kandungan materialnya lebih murni (Mak, Hamid, Liu, Lu, \& White, 2013).

Senyawa bioaktif yang memiliki peranan sebagai antioksidan adalah senyawa yang mampu menghambat kerusakan pada sel normal, protein dan lemak yang ditimbulkan oleh radikal bebas (Septian \& Widyaningsih, 2013). Fukoidan merupakan antioksidan alami dan berpotensi mencegah penyakit yang disebabkan oleh radikal bebas (Mak et al., 2013). Kemampuan antioksidan fukoidan melalui interaksinya dengan radikal bebas (Li, Rui, \& Xin, 2008). Korelasi kandungan sulfat dan kemampuan menangkap radikal bebas adalah berbanding lurus. Rasio kandungan sulfat/fukosa merupakan indikasi aktivitas sebagai antioksidan (Wang, Zhang, Zhang, \& Li, 2008). Fukoidan yang telah diisolasi dari beberapa jenis alga cokelat terbukti memiliki komponen aktif antiviral, antioksidan, antikanker, serta antikoagulan (Sinurat \& Marraskuranto, 2011). Beberapa senyawa bioaktif yang sudah diteliti mempunyai kemampuan sebagai antioksidan di antaranya fukoidan dan komponen fenolik (Luthfiyana, Nurjanah, Nurilmala, Anwar, \& Hidayat, 2016), sedangkan ekstrak metanol $S$. echinocarpum dan Padina sp., mengandung senyawa fenolik, tanin, saponin, glikosida dan steroid yang memiliki aktivitas antioksidan (Firdaus et al. 2012; Foon, Ai, Kuppusamy, Yusoff, \& Govindan, 2013). Ekstrak etanol S. wightiimemiliki aktivitas antioksidan

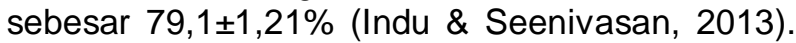
Seftylia, Nurjanah, dan Asadatun (2017) menyatakan senyawa bioaktif dari S. polycystum, P. minor dan $T$. conoides mempunyai daya antioksidan yang kuat. Ukuran berat molekul mempengaruhi kemampuan bioaktivitasnya. Hidrolisis fukoidan menggunakan asam dapat mempengaruhi bioaktivitasnya sebagai antikanker (Sinurat, Saepudin, \& Qosthalani, 2017).

Depolimerisasi adalah proses konversi polimer menjadi komponen berukuran lebih pendek. Proses depolimerisasi ini dapat dilakukan dengan beberapa cara, di antaranya secara kimia, fisik, radiasi dan enzimatis. Depolimerisasi secara kimiawi, enzimatis, maupun radiasi berpotensi memecah rantai polisakarida menjadi fraksi-fraksi oligosakarida yang lebih sederhana. Hidrolisis secara kimiawi dengan menggunakan asam, merupakan metode yang umum digunakan untuk memotong berbagai macam struktur polisakarida. Prinsipnya adalah pemutusan rantai glikosida polisakarida menjadi unit-unit monosakarida. Namun, selain terputusnya ikatan glikosida kemungkinan juga disebabkan oleh terputusnya gugus sulfat dalam rantai fukoidan. Dalam penelitian ini akan dilakukan variasi waktu hidrolisis fukoidan, sedangkan optimasi konsentrasi asam dan temperatur, menggunakan hasil penelitian sebelumnya (Sinurat et al., 2017). Penelitian ini bertujuan untuk mengetahui pengaruh hidrolisis fukoidan terhadap aktivitasnya sebagai antioksidan.

\section{BAHAN DAN METODE}

\section{Bahan}

Peralatan dan instrumen yang digunakan dalam penelitian ini di antaranya adalah glassware yang rutin 
digunakan di laboratorium dan Instrumen yang digunakan adalah FTIR, vakum rotavapor (Buchi) dan spektrofotometer UV-VIS (Perkin elmer), microplate reader spectrophotometer (Thermo).

Bahan baku yang digunakan dalam penelitian ini adalah rumput laut cokelat Sargassum crassifolium yang diperoleh dari Desa Tarahan, Lampung Selatan, Indonesia. Bahan kimia yang digunakan antara lain Trifluoroacetic acid (TFA) untuk hidrolisis fukoidan, standar monomer (fukosa dan xylosa), kristal 1,1difenil-2-pikrilhidrazil (DPPH) p.a (Sigma-Aldrich) untuk uji antioksidan dan Vitamin C (L(+)-Ascorbic Acid) No. Cat 1.00468.1000 (Merck) untuk kontrol positif uji antioksidan.

\section{Metode}

\section{Preparasi sampel rumput laut cokelat}

Rumput laut cokelat basah dicuci sampai bersih, ditiriskan, kemudian dipotong-potong dan ditimbang. Rumput laut cokelat tersebut selanjutnya direndam dengan etanol teknis (1:5) selama 24 jam, kemudian dikeringkan dalam lemari pengering dengan suhu $35^{\circ} \mathrm{C}$ selama 24 jam. Rumput laut cokelat yang telah kering siap untuk diekstraksi.

Rumput laut cokelat kering diekstraksi dengan $\mathrm{HCl}$ $0,1 \mathrm{~N}(1: 10)$ dalam waterbath, dengan suhu $85^{\circ} \mathrm{C}$ selama 6 jam. Residu dipisahkan dari filtratnya menggunakan planktonet 500 mesh, filtrat ditampung dan ditambahkan $\mathrm{CaCl}_{2} 2 \%(\mathrm{~b} / \mathrm{v})$, diaduk dan dibiarkan selama 4 jam. Endapan dipisahkan dari filtratnya dengan cara sentrifugasi selama 15 menit, kecepatan $8000 \mathrm{rpm}$ dengan suhu $4^{\circ} \mathrm{C}$. Filtrat ditampung dan ditambahkan etanol teknis (1:2) selanjutnya didiamkan semalam. Ekstrak fukoidan yang terbentuk dipisahkan dari etanol dengan cara evaporasi. Kemudian endapannya dibekukeringkan untuk mendapatkan ekstrak fukoidan (Sinurat et al., 2017).

\section{Hidrolisis ekstrak fukoidan}

Ekstrak fukoidan $(50 \mathrm{mg}$ ) ditambahkan $5 \mathrm{~mL}$ TFA $1 \mathrm{M}(10: 1)$ dalam botol kaca, kemudian dimasukkan ke dalam autoklaf dengan suhu $121^{\circ} \mathrm{C}$ tekanan $1 \mathrm{~atm}$, dengan variasi waktu inkubasi 30, 60, 90 dan 120 menit. Kemudian, hasil hidrolisis disentrifugasi dengan kecepatan 8000 rpm selama 15 menit, filtrat ditampung dan dinetralkan dengan $\mathrm{NaOH}$. Setelah netral filtrat dikeringkan dengan konsentrator, untuk mendapatkan ekstrak fukoidan yang telah dihidrolisis.

Pengamatan data meliputi kadar sulfat dengan metode BaCl2 -Gelatin (Dodgson \& Price, 1961); total polisakarida menggunakan monomer heksosa (fukosa) dan pentosa (xilosa) dengan metode Dubois, Gilles, Hamilton, Rebers, dan Smith (1956); identifikasi gugus fungsi fukoidan menggunakan FTIR dan uji antioksidan menggunakan metode DPPH ( $\mathrm{Li}$ et al., 2006; Nursid, Januar, dan Chasanah, 2008).

\section{HASIL DAN PEMBAHASAN}

Ekstraksi menggunakan asam lemah menghasilkan rendemen fukoidan sebesar $23,82 \%$ dari rumput laut cokelat kering jenis Sargassum crassifolium. Hasil ekstraksi selanjutnya di hidrolisis dengan variasi waktu. Hasil penelitian menunjukkan bahwa variasi waktu hidrolisis mempengaruhi rendemen fukoidan. Semakin lama waktu hidrolisis yang dilakukan rendemen fukoidan yang dihasilkan semakin tinggi (Tabel 1).

Hasil mutu fukoidan yang dihidrolisis juga bervariasi. Semakin lama waktu hidrolisis kandungan total polisakaridanya semakin meningkat; demikian juga kandungan sulfatnya yang menunjukkan semakin banyak fukoidan yang terhidrolisis. Hidrolisis optimun yang diperoleh berdasarkan kandungan sulfat dan total polisakaridanya adalah pada waktu 90 menit dengan konsentrasi 1,5M TFA. Hidrolisis setelah 120 menit menunjukkan kandungan fukosa yang menurun, karena kemungkinan monomer terurai menjadi senyawa yang lebih kecil (Tabel 2).

\section{Analisis Gugus Fungsi dengan FT-IR}

Karakterisasi fukoidan dengan instrumen FT-IR memberikan informasi keberadaan gugus fungsi ester sulfat pada rantai fukoidan serta posisi pengikatannya,

Tabel 1. Rendemen fukoidan hasil hidrolisis berdasarkan variasi waktu

Table 1. Fucoidan yield resulted from hydrolysis with various times

\begin{tabular}{cc}
\hline Waktu (menit)/Time (minute) & Rendemen/ Yield(\%) \\
\hline 30 & $43.30 \pm 1.92$ \\
60 & $64.59 \pm 0.64$ \\
90 & $76.56 \pm 1.53$ \\
120 & $77.59 \pm 0.64$ \\
\hline
\end{tabular}


Tabel 2. Total polisakarida dari fukoidan hasil hidrolisis dengan variasi waktu Table 2. Total polysaccharides of fucoidan resulted from hydrolisis with various time

\begin{tabular}{|c|c|c|c|c|}
\hline $\begin{array}{l}\text { Sampel/ } \\
\text { Sample }\end{array}$ & $\begin{array}{c}\text { Kadar Fukosa/ } \\
\text { Fucosa Content } \\
(\%)\end{array}$ & $\begin{array}{l}\text { Kadar Xilosa/ } \\
\text { Xilosa Content } \\
\text { (\%) }\end{array}$ & $\begin{array}{c}\text { Kadar Total Polisakarida/ } \\
\text { Polysacharide Total } \\
\text { Content }(\%)\end{array}$ & $\begin{array}{c}\text { Kadar Sulfat/ } \\
\text { Sulphate Content } \\
(\%)\end{array}$ \\
\hline HF 1.5 M30m & $20.16 \pm 0.32$ & $2.71 \pm 0.21$ & $22.87 \pm 0.23$ & $4.09 \pm 0.23$ \\
\hline HF 1.5 M60m & $38.54 \pm 0.64$ & $1.66 \pm 0.20$ & $40.20 \pm 0.54$ & $12.42 \pm 0.32$ \\
\hline HF 1.5 M90m & $42.26 \pm 0.83$ & $1.3 \pm 0.14$ & $43.56 \pm 0.61$ & $13.09 \pm 0.36$ \\
\hline HF $1.5 \mathrm{M} 120 \mathrm{~m}$ & $31.00 \pm 0.42$ & $0.8 \pm 0.02$ & $31.80 \pm 0.42$ & $11.20 \pm 0.34$ \\
\hline Standar Fukoidan/Fucoidan standard (PF) & $56.41 \pm 0.85$ & $3.36 \pm 0.23$ & $59.77 \pm 0.57$ & $26.57 \pm 0.45$ \\
\hline Fukoidan kasar/Crude Fukoidan (CF) & $46.28 \pm 0.76$ & $4.41 \pm 0.22$ & $50.69 \pm 0.59$ & $19.44 \pm 0.50$ \\
\hline
\end{tabular}

Keterangan/Note:

HF : Fukoidan yang dihidrolisis/Hydrolized fucoidan

baik aksial maupun ekuatorial. Gugus ester sulfat simetris $(\mathrm{O}=\mathrm{S}=\mathrm{O})$ akan menyerap pada pita absorbsi $1240-1260 \mathrm{~cm}^{-1}$, sedangkan ester sulfat asimetris $(\mathrm{O}-$ $\mathrm{S}=0$ ) menyerap pada pita absorbsi $1030-1060 \mathrm{~cm}^{-1}$. Selain itu, data serapan Infra Red (IR) pada fukoidan dapat memberikan informasi posisi ester sulfat aksial $\left(840 \mathrm{~cm}^{-1}\right)$ dan ekuatorial $\left(820 \mathrm{~cm}^{-1}\right)$.
Berdasarkan hasil pengukuran FT-IR, sampel crude fukoidan (Gambar 1.A) memiliki serapan gugus ester sulfat simetris pada bilangan gelombang $1254 \mathrm{~cm}^{-1}$. Serapan pada bilangan gelombang $819 \mathrm{~cm}^{-1}$ menginformasikan posisi ester sulfat ekuatorial. Sedangkan pada fukoidan yang dihidrolisis (Gambar 1.B), serapan ester sulfat asimetris muncul pada bilangan
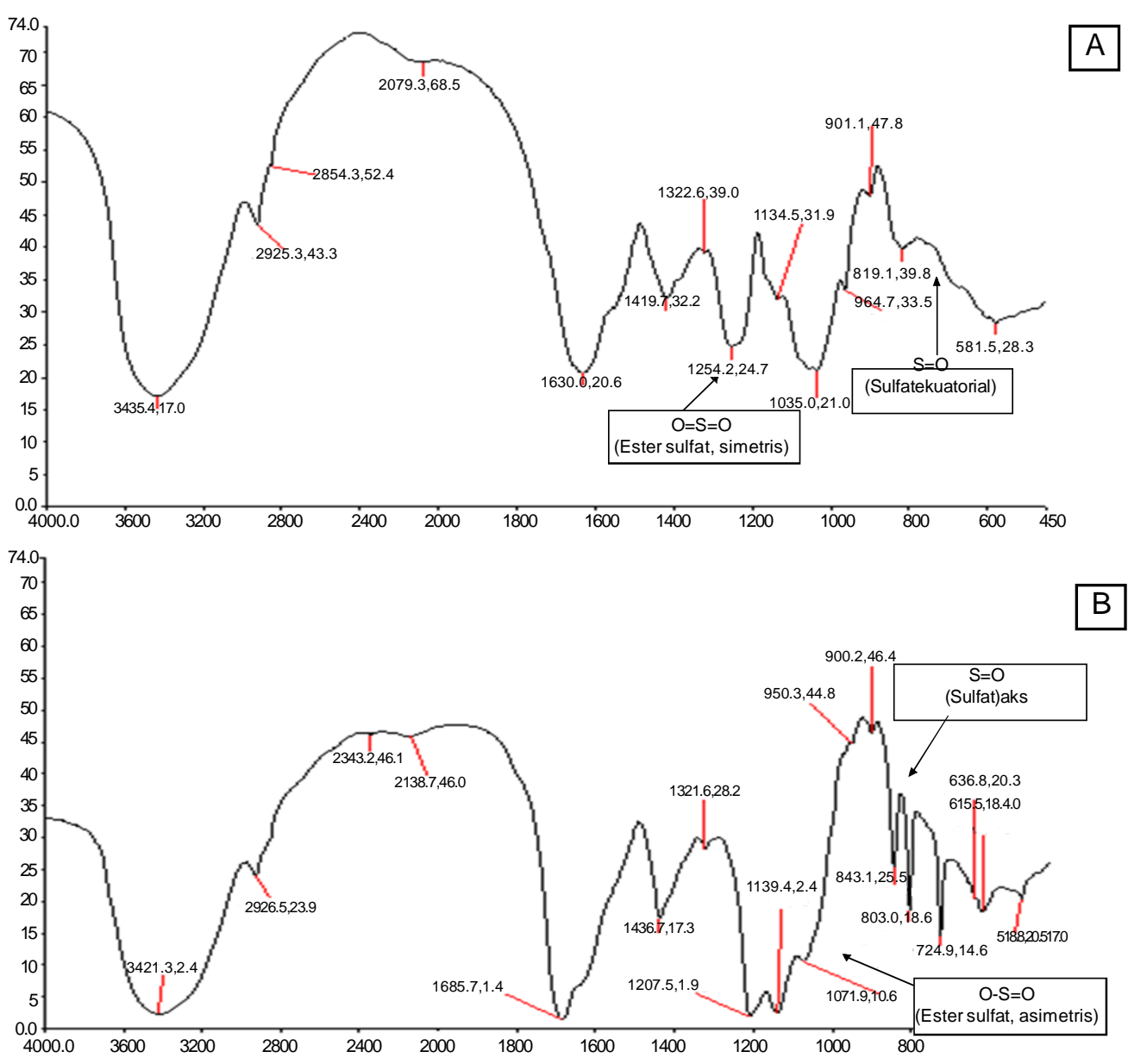

Gambar 1. A. Spektra FT-IR crude fukoidan B. Spektra FT-IR fukoidan hidrolisis Figure 1. A. FT-IR Spectra of crude fucoidan B. FT-IR spectra of hidrolyzed fucoidan 
gelombang $1072 \mathrm{~cm}^{-1}$ dan sulfat aksial pada bilangan gelombang $843 \mathrm{~cm}^{-1}$. Hal tersebut menggambarkan bahwa perlakuan hidrolisis asam berpengaruh terhadap pengikatan dan konformasi gugus ester sulfat. Hidrolisis mengubah konformasi gugus ekuatorial menjadi aksial, sehingga posisi sulfatnya menjadi kurang stabil dan berpotensi mempengaruhi aktivitasnya.

\section{Uji Aktivitas Fukoidan dengan Metode DPPH}

Prinsip uji antioksidan metode DPPH yaitu antioksidan mendonorkan proton ke DPPH yang berwarna ungu sehingga terbentuk senyawa tidak radikal dan ditandai dengan perubahan warna menjadi kuning pucat. Indikasi perubahan warna ini menunjukkan aktivitas penangkap radikal bebas (Szabo, Iditoiu, Chambre, \& Lupea, 2007). Perubahan warna tersebut dilakukan dengan menggunakan spektrofotometer visibel pada panjang gelombang 517 $\mathrm{nm}$. Metode DPPH dipilih karena memiliki beberapa kelebihan, yaitu metode ini sederhana, tahapan pengujian singkat dan bahan-bahan yang digunakan mudah diperoleh. Pada penelitian ini dilakukan uji antioksidan pada sampel crudefukoidan (CF), fukoidan yang telah dihidrolisis dengan TFA (HF) serta fukoidan standar (PF) yang memiliki kemurnian yang tinggi dan asam askorbat yang digunakan sebagai kontrol positif.

Melalui hasil penelitian ini diketahui bahwa fukoidan standar (PF) memiliki aktivitas antioksidan yang paling baik dengan $I_{50}$ sebesar 723 ppm. Selanjutnya

Tabel 3. Hasil uji antioksidan untuk masing-masing sampel

Table 3. The result of antioxidant test for each sample

\begin{tabular}{|c|c|c|c|}
\hline $\begin{array}{l}\text { Sampel/ } \\
\text { Sample }\end{array}$ & $\begin{array}{c}\text { Konsentrasi/ } \\
\text { Concentration (ppm) }\end{array}$ & $\begin{array}{l}\text { \% Hambatan/ } \\
\% \text { Inhibition }\end{array}$ & $\mathrm{IC}_{50}(\mathrm{mg} / \mathrm{L})$ \\
\hline \multirow{4}{*}{ HF 30m } & 15000 & 15 & \multirow{4}{*}{57.043} \\
\hline & 20000 & 20 & \\
\hline & 25000 & 26 & \\
\hline & 30000 & 31 & \\
\hline \multirow{4}{*}{$\mathrm{HF} 60 \mathrm{~m}$} & 15000 & 30 & \multirow{4}{*}{34.447} \\
\hline & 20000 & 35 & \\
\hline & 25000 & 42 & \\
\hline & 30000 & 47 & \\
\hline \multirow{4}{*}{ HF 90m } & 15000 & 30 & \multirow{4}{*}{23.470} \\
\hline & 20000 & 40 & \\
\hline & 25000 & 55 & \\
\hline & 30000 & 61 & \\
\hline \multirow{4}{*}{ HF $120 m$} & 15000 & 21 & \multirow{4}{*}{27.193} \\
\hline & 20000 & 30 & \\
\hline & 25000 & 44 & \\
\hline & 30000 & 58 & \\
\hline \multirow{4}{*}{$\mathrm{CF}$} & 7500 & 3 & \multirow{4}{*}{14.844} \\
\hline & 10000 & 20 & \\
\hline & 12500 & 33 & \\
\hline & 15000 & 48 & \\
\hline \multirow{4}{*}{ PF } & 300 & 30 & \multirow{4}{*}{723} \\
\hline & 600 & 47 & \\
\hline & 900 & 55 & \\
\hline & 1200 & 61 & \\
\hline \multirow{4}{*}{ Vit C } & 4 & 26 & \multirow{4}{*}{9} \\
\hline & 6 & 37 & \\
\hline & 8 & 47 & \\
\hline & 10 & 54 & \\
\hline
\end{tabular}

Keterangan/Note :

$\mathrm{HF}$ : Fukoidan yang dihidrolisis/Hydrolized fucoidan CF : Crude fucoidan

PF : Fukoidan yang dimurnikan/Purified fucoidan Vit C : Vitamin C/Vitamin C 
sampel crude fukoidan (CF) memiliki nilai $\mathrm{IC}_{50}$ sebesar 14,84 ppm dan nilai $\mathrm{IC}_{50}$ fukoidan hasil hidrolisis $\mathrm{HF}$ 30m, HF 60m, HF 90m, dan HF 120m masing-masing sebesar 57,04, 34,45; 23,47 dan 27,19 ppm. Hasil pengujian menunjukkan bahwa kemampuan antioksidan berbanding lurus dengan kandungan sulfat fukoidan. Hal ini dapat dibuktikan seperti yang tertera dalam Gambar 2, pada konsentrasi fukoidan yang sama (1000 ppm) tetapi dengan kandungan sulfat yang semakin tinggi akan menghasilkan persen hambatan yang semakin tinggi. Hal ini sejalan dengan beberapa pustaka yang menyatakan bahwa jumlah kadar sulfat fukoidan mempengaruhi kemampuan antioksidannya. Semakin tinggi kadar sulfat, maka kemampuan sebagai antioksidannya semakin tinggi (Mak et al., 2013).

Fukoidan hasil hidrolisis belum memiliki aktivitas antioksidan yang baik. Dalam penelitian ini diharapkan fukoidan yang terdepolimerisasi memiliki aktivitas antioksidan yang lebih baik dibandingkan dengan crude fukoidan. Kemungkinan besar hal ini disebabkan karena fukoidan belum terhidrolisis sempurna sehingga belum terbentuk oligomer fukoidan.

Jika dilihat kemampuan antioksidan crude fukoidan dibandingkan fukoidan yang dihidrolisis untuk semua variasi waktu, kemampuan antioksidan fukoidan yang dihidrolisis lebih rendah (Gambar 2). Kemampuan antioksidan berbanding lurus dengan kandungan sulfat yang terdapat pada fukoidan. Kemungkinan sulfat sangat mempengaruhi pada bioaktivitas fukoidan sebagai antioksidan. Kemampuan antioksidan fukoidan komersil lebih tinggi dibandingkan pada semua produk fukoidan karena kandungan sulfat fukoidan yang lebih tinggi (18,66\%). Hal ini dilihat dari persen hambatannya yang lebih tinggi (59,3\%). Fukoidan dalam larutan bersifat ionik karena mengandung sulfat yang bersifat anion, sehingga membuat fukoidan dapat berinteraksi dengan senyawa lain. Hal ini yang mengakibatkan kandungan sulfat sangat berperan dalam akitvitasnya. Selain itu posisi sulfat pada atom karbon juga mempengaruhi aktivitasnya (Marcel \& Anne, 2013; Mak et al., 2013). Untuk $\mathrm{IC}_{50}$ vitamin $\mathrm{C}$ sebagai kontrol positif paling tinggi persen hambatannya $(54,5 \%)$ dalam konsentrasi 10 ppm, dibandingkan pada semua produk fukoidan (fukoidan komersil, crude fukoidan maupun fukoidan hidrolisis secara keseluruhan). Hal ini kemungkinan disebabkan fukoidan memiliki mekanisme yang berbeda dalam menetralkan radikal bebas DPPH yang sebanding dengan kontrol positifnya (asam askorbat). Vitamin C atau L- asam askorbat mampu menangkap radikal bebas hidroksil. Kemampuan menangkap radikal bebas disebabkan karena asam askorbat memiliki pendonor elektron berupa gugus enadiol, sehingga mencegah terbentuknya senyawa lain akibat oksidasi dengan melepaskan satu rantai karbon (Padayatty, 2003). Berdasarkan hasil analisis yang diperoleh fukoidan termasuk golongan antioksidan yang sangat lemah karena $\mathrm{IC}_{50}$ berada diatas $200 \mathrm{ppm}$. Bahriul, Rahman dan Diah (2014) menyatakan bahwa nilai $I_{50}$ kurang dari $50 \mathrm{mg} / \mathrm{L}$ mempunyai aktivitas antioksidan tergolong kuat, $50-100 \mathrm{mg} / \mathrm{L}$ sedang, 150$200 \mathrm{mg} / \mathrm{L}$ lemah dan lebih dari $200 \mathrm{mg} / \mathrm{L}$ sangat lemah. Berdasarkan teori tersebut crude fukoidan masih termasuk antioksidan sangat lemah. Nilai $I_{50}$ yang

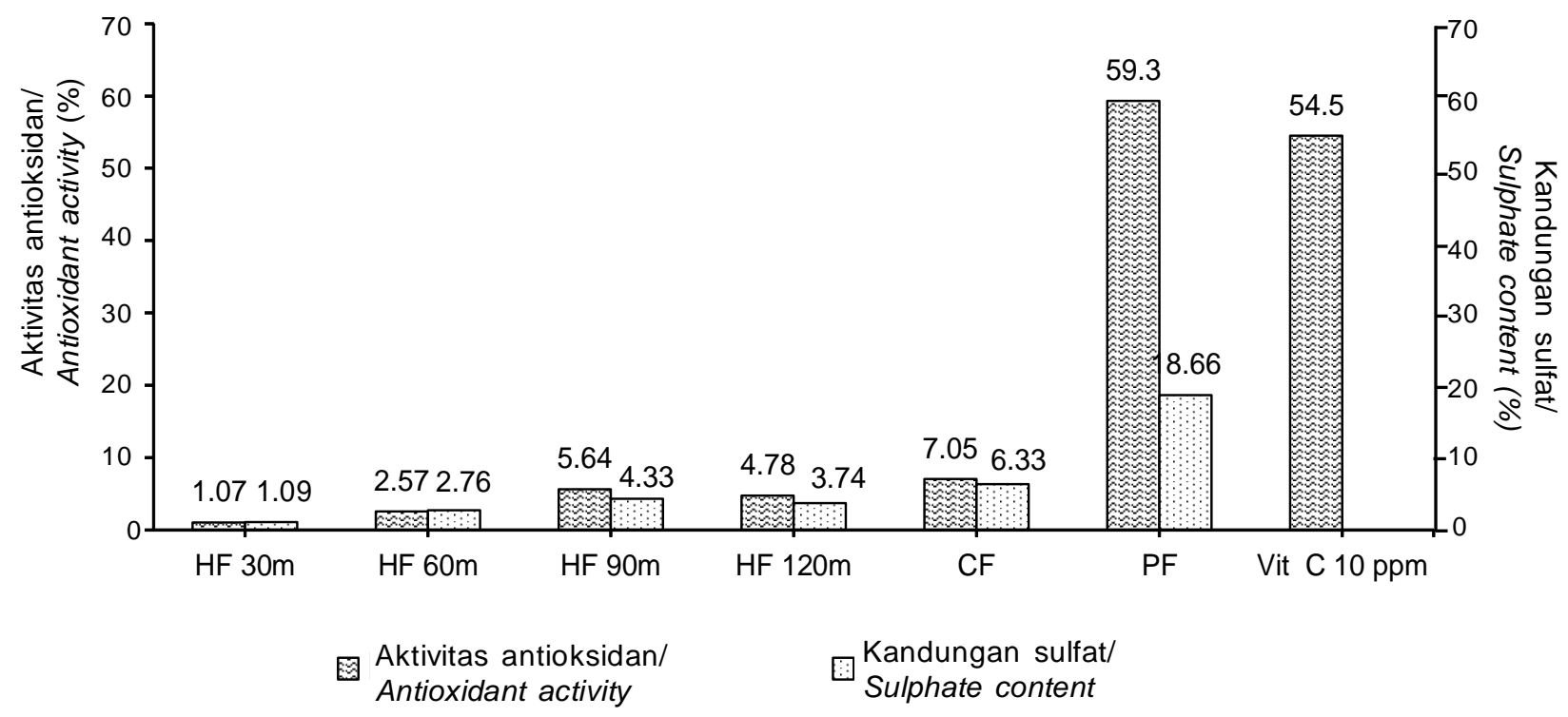

Gambar 2. Aktivitas fukoidan pada konsentrasi yang sama (1000 mg/mL) dengan metode DPPH

Figure 2. Fucoidan activity at same concentration $(1000 \mathrm{mg} / \mathrm{mL})$ by DPPH Method 
rendah menunjukkan kemampuan yang kuat dari ekstrak untuk berperan sebagai donor atom hidrogen (Sarini, Aishah, \& Zaini, 2014).

Kandungan sulfat yang tinggi menunjukkan kekuatan pemutusan radikal bebas yang kuat. Hal ini telah dibuktikan dengan membandingkan fraksi fukoidan yang rendah sulfat dengan fukoidan tinggi sulfat dari Padina gymnospora (Rocha De Souza et al., 2007). Beberapa hasil penelitian tentang fukoidan sebagai antioksidan dari jenis Undaria pinnatifida melaporkan bentuk crude fukoidan lebih tinggi aktivitas antioksidannya dibandingkan dengan hasil fraksi dengan berat molekul lebih pendek. Selain sulfat kemungkinan kandungan polifenol juga mempengaruhi aktivitasnya (Mak et al., 2013). Kandungan total fenol berkorelasi positif terhadap aktivitas antioksidan. Senyawa fenol memiliki aktivitas antioksidan karena mempunyai gugus hidroksil tersubstitusi pada posisi orto dan para (Andayani, Maimunah, \& Lisawati, 2008). Secara umum bioaktivitas fukoidan sangat dipengaruhi oleh kandungan sulfatnya, hal ini terlihat dari beberapa hasil penelitian yang sudah dilakukan seperti pada bioaktivitas fukoidan sebagai anti kanker yang dilaporkan bahwa kandungan sulfat fukoidan 18,63\% memiliki bioaktivitas antikanker lebih tinggi dibandingkan dengan fukoidan dengan kandungan sulfat $8,69 \%$ (Sinurat et al., 2017). Faktor lain yang mempengaruhi bioaktivitas fukoidan adalah teknik ekstraksi yang dapat mengubah struktur fukoidan (Ponce, Pujol, Damonte, Flores, \& Stortz, 2003) dikarenakan hidrolisis yang dilakukan mampu mengubah bioaktivitasnya sebagai antioksidan, dalam hal ini penggunaan asam selain memutus rantai glikosida kemungkinan juga memutus ikatan sulfatnya. Kemampuan menangkap radikal bebas erat hubungannya dengan kelompok hidroksil yang ada pada senyawa fenolik (Mehdinezhad, Ghannadi, \& Yegdaneh, 2016). Rumput laut cokelat Sargassum juga memiliki kandungan fenol yang tinggi. Kandungan fenolik pada alga cokelat sebesar $20-30 \%$ (Gazali et al., 2018). Florotanin merupakan senyawa fenolik utama yang terdeteksi di dalam alga cokelat (Koivikko, 2008).

\section{KESIMPULAN}

Kesimpulan dari hasil penelitian ini adalah :

1. Hasil optimasi waktu hidrolisis crude fukoidan yaitu 90 menit menggunakan TFA 1,5M yang menghasilkan rendemen, kandungan polisakarida dan sulfat masing-masing $76,56 \%, 43,56 \%$ dan $13,09 \%$.

2. Nilai $I \mathrm{C}_{50}$ crude fukoidan dan fukoidan komersil lebih tinggi dibandingkan seluruh fukoidan hasil hidrolisis.
3. Kandungan sulfat dalam fukoidan mempengaruhi kemampuan daya antioksidannya.

4. Crude fukoidan termasuk antioksidan sangat lemah (berdasarkan metode DPPH.

\section{DAFTAR PUSTAKA}

Andayani, R., Maimunah., \& Lisawati, Y. (2008). Penentuan aktivitas antioksidan, kadar fenolat total dan likopen pada buah tomat (Solanum lycopersicum) L). J Sains Teknologi Farma, 13(1), 31-37.

Anggadiredja, J. T. (2006). Rumput Laut. Penebar Swadaya. Jakarta.

Bahriul, P., Rahman, N., \& Diah, A. W. M. (2014). Uji aktivitas antioksidan ekstrak daun salam (Syzygium polyanthum) dengan menggunakan 1,1-difenil-2pikrilhidrazil. Jurnal Akademia Kimia, 3(3), 143-149.

Dubois, M., Gilles, K. A., Hamilton, J. K., Rebers, P. A., \& Smith, F. (1956). Colorimetric method for determination of sugars and related substances. Anal. Chem. 28, 350-6. Seaweed Sargassum stenophyllum. Carbohydr. Res, 333, 281-293.

Dodgson, K. S., \& Price, R. G. (1962). A note on the determination of the ester sulphate content of sulphated polysaccharides. Biochemistry, 84, 106110.

Firdaus, M., Astawan, M., Muchtadi, D., Wresdiyati, T., Waspadji, S., \& Karyono S. S. (2012). Toksisitas akut ekstrak metanol rumput laut cokelat Sargassum echinocarpum. Jurnal Pengolahan Hasil Perikanan Indonesia, 15(2), 148-155.

Foon, T. S., Ai, L. A., Kuppusamy, P., Yusoff, M. M., \& Govindan, N. (2013). Studies on In-Vitro antioxidant activity of marine edible seaweeds from the east coastal region of peninsular malaysia using different extract methods. Journal of Coastal Life Medicine, 1(3),193-198.

Gazali, M., Nurjanah, N., Zamani, N. (2018). Eksplorasi senyawa bioaktif alga cokelat Sargassum sp. Agardh sebagai antioksidan dari Pesisir Barat Aceh. Jurnal Pengolahan Hasil Perikanan Indonesia 2018, 21(1),167-178.

Indu, H., \& Seenivasan, R. (2013). In Vitro antioxidant activity of selected seaweeds from southeast coast of India. International Journal of Pharmacy and Pharmaceutical Sciences, 5(2), 474-484.

Indriani, H. \& Sumiarsih, E. (1992). Budidaya, pengolahan dan pemasaran rumput laut. Jakarta: Penebar Swadaya.

Jeeva, S., Marimuthu, J., Domettila, C., Anantham, \& Mahesh, M. (2012). Preliminary phytochemical studies on some selected seaweeds from gulf of Mannar, India. Asian Pacific Journal of Tropical Biomedicine, S30-S33.

Koivikko, R. (2008). Brown algal phlorotannins: improving and applying chemical methods. University of Turku, Turku, Finland, 1-61. http://www.doria.fi/ bitstream/ handle/10024/36054/AI381. pdf? sequence $=1$. 
Li, B., Rui, X. Z., \& Xin, J. W. (2008). Anticoagulant activity of fucoidan from Hizikia fusiforme. Agro Food Industry Hi-tech., 19, 22-24.

LI, Y., Li, X., Lee, U., Kang, J. S., Choi, H. D., \& Son, B. W. (2006) A new radical scavenging antharacene glycoride, asperflavin ribofuranoside and polyketides from a marine isolate of the fungus. Microsporum, Chem. Pharm. Bull, 54(6), 882-883.

Li, G. Y., Lou, Z. C., Yuan, F., \& Yu, X. B. (2017). Combined Process of high-pressure homogenization and hydrothermal extraction for the extraction of fucoidan with good antioxidant properties from Nemacystus decipients. Food and Bioproducts Processing, 106, 35-42. https://doi.org/10.1016/j.fbp.2017.08.002.

Luthfiyana, N., Nurjanah., Nurilmala, M., Anwar, E., \& Hidayat, T. (2016). Rasio bubur rumput laut Eucheuma cottonii dan Sargassum sp. sebagai formula krim tabir surya. Jurnal Pengolahan Hasil Perikanan Indonesia, 19(3), 183-195.

Machu, L., Misurcova, L., Ambrozova, JV., Orsavova, J., Mlcek, J., Sochor, J., \& Jurikova, T. (2015). Phenolic content and antioxidant capacity in algal food products. Molecules, 20, 1118-1133.

Mak, W., Hamid, N., Liu, T., Lu, J., \& White, W. I. (2013). Fucoidan from New Zealand Undaria pinnatifida: monthly variations and determination of antioxidant activities. Carbohydrate Polymers, 95, 606-614.

Marcel, T. A. \& Anne, S. M. (2013). Fucoidans from brown seaweeds: an update on structures, extraction techniques and use of enzymes as tools for structural elucidation. The Royal Society of Chemistry Advance, p:8131-814. DOI: 10.1039/c3ra23373a. www.rsc.org/ advances.

Mehdinezhad, N., Ghannadi, A., \& Yegdaneh, A. (2016). Phytochemical and biological evaluation of some Sargassum species from Persian Gulf. Research in Pharmaceutical Sciences, 11(3), 243-249.

Nursid, M., Januar, H.I., \& Chasanah, E. (2008). Purifikasi dan identifikasi senyawa antioksidan dari spons Aaptos sp. Jurnal Pascapanen dan Bioteknologi Kelautan dan Perikanan, 2(1), 55-62.

Padayatty, S. J., Katz, A., Wang, Y., Eck, P., Kwon, O., Lee, J. H., ... Dutta, S. K. (2003). Vitamin C as an antioxidant: evaluation of its role in disease prevention. Journal of the American College of Nutrition, 22(1), 18-35.

Ponce N. M., Pujol, C. A., Damonte, E. B., Flores, M. L., Stortz C. A. (2003). Fucoidans from the brown seaweed Adenocystis utricularis: extraction methods, antiviral activity and structural studies. Carbohydrate Research, 338, 153-165.

Rocha De Souza, M., Marques, C., Guerra Dore, C., Ferreira Da Silva, F., Oliveira Rocha, H., Leite, E. (2007). Antioxidant activities of sulfated polysaccharides from brown and red seaweeds. Jurnal Applied Phycology, 19(2), 153-160

Sarini, A. W., Aishah, H. N., \& Zaini, N. M. (2014). Determination of antioxidant activity for seven types of macroalgae. International Conference on Food Engineering and Biotechnology, 65, 51-56.

Sinurat, E., Saepudin, E., \& Qosthalani, FA., (2017). Effect of hydrolyzed fucoidan from the brown seaweed Sargassum binderi sonder towards human breast cancer T47d cell lines. Squalen Bull of Mar and Fish. Postharvest and Biotech., 12 (2), 49-55.

Sinurat, E., \& Marraskuranto, E. (2011). Fucoidan from brown seaweed and its bioactivity. Squalen Bull. of Marine and Fishieries Postharvest and Biotech., 7(3), 131-37.

Sinurat, E., Saepudin, E., \& Peranginangin, R. (2015). Purification and characterization of fucoidan from the brown seaweed Sargassum binderi Sonder. Squalen Bull of Marine and Fishieries Postharvest and Biotech, 10(2), 79 -87.https://doi.org/10.15578/ squalen.v10i2.133.

Seftylia, D., Nurjanah, \& Asadatun, A., (2017). Aktivitas antioksidan berbagai jenis rumput laut coklat dari perairan kepulauan seribu. JPHPI, 20(2), 305-3018.

Septiana, A. T., \& Asnani A. (2013). Aktivitas antioksidan ekstrak rumput laut Sargassum duplicatum. Jurnal Teknologi Pertanian, 14(2), 79-86.

Septian, B. A., \& Widyaningsih, T. D. (2014). Peranan senyawa bioaktif minuman cincau hitam (Mesona palustris $\mathrm{BI}$ ) terhadap panurunan tekanan darah tinggi: kajian pustaka. Jurnal Pangan Agroindustri, 2(3), 198-202.

Szabo, M. R., Iditoiu, C., Chambre, D., \& Lupea, A. X. (2007). Improved DPPH determination for antioxidant activity spectrophotometric assay. Chemical Papers Chemicke Zvesti, 61, 214-216.

Wang, J., Zhang, Q., Zhang, Z., \& Li, Z. (2008). Antioxidant activity of sulfated polysaccharide fractions extracted from Laminaria japonica. International Journal Biology Macromolecule, 42(2), 127-32. 